\title{
PSA Level Two to Ten
}

National Cancer Institute

\section{Source}

National Cancer Institute. PSA Level Two to Ten. NCI Thesaurus. Code C148266.

A blood concentration of prostate specific antigen between 2 and $10 \mathrm{ng} / \mathrm{mL}$. 